on the chromosomes of the salivary glands in Drosophila in relation to the problems of mutation and genetics, published in Genetics and the Journal of Heredity in 1934; John J. Carty Medal, and award for the advancement of science, consisting of a gold medal, bronze replica, certificate and 3,000 dollars, awarded to Sir William Bragg, of the Royal Institution, London, for his fundamental work in $\mathrm{X}$-ray crystal analysis; he has shown how to reveal the constitution of crystalline forms and accurately measure them, and his studies have given birth to a new tool which is bringing to light important facts regarding such complex structures as the larger organic molecules.

\section{U.S. National Academy of Sciences: Elections}

AT the annual meeting of tho National Academy of Sciences, Dr. Frank B. Jewett, president of the Bell Telephone Laboratories, was elected president for a term of four years, to succeed Dr. Frank $\mathbf{R}$. Lillie, emeritus professor of zoology of the University of Chicago, who will retire on June 30. The following were elected members of the Academy: Gregory Breit, professor of physics, University of Wisconsin; Detlev Wulf Bronk, Johnson professor of biophysics and director of the Johnson Foundation, University of Pennsylvania; William Bosworth Castle, associate professor of medicine, Harvard Medical School, director of the Thorndike Memorial Laboratory, Boston City Hospital ; Frederick Gardner Cottrell, president, Research Associates, Incorporated, Washington, D.C., consulting chemist, Bureau of Chemistry and Soils; Frederick Parker Gay, professor of pathology and bacteriology, College of Physicians and Surgeons, Columbia University; Albert Baird Hastings, Hamilton Kuhn professor of biochemistry, Harvard University; Vladimir Nikolaevich Ipatieff, research director of the Universal Oil Products Company, professor of chemistry, Northwestern University; Merkel Henry Jacobs, professor of general physiology, University of Pennsylvania; Zay Jeffries, General Electric Company, Cleveland, Ohio ; Donald Forsha Jones, geneticist, Connecticut Agricultural Experiment Station, New Haven; George Bogdan Kistiakowsky, professor of chemistry, Harvard University; Warren Judson Mead, pro. fessor and head of the department of geology, Massachusetts Institute of Technology; Oscar Riddle, investigator, department of genetics, Station for Experimental Evolution, Carnegie Institution, Cold Spring Harbor, N.Y. ; Adolph Hans Schultz, associate professor of physical anthropology, School of Medicine, the Johns Hopkins University; Philip Edward Smith, professor of anatomy, College of Physicians and Surgeons, Columbia University.

THE following were elected foreign associates: Sir Joseph Barcroft, professor of physiology, University of Cambridge; Sir William Bragg, director, Royal Institution of Great Britain and Fullerian professor of chemistry and director of the Davy Faraday Research Laboratory; Dr. F. A. Vening Meinesz, professor of geodesy and cartography, the University of Utrecht.

\section{Franklin Medals}

Frankurn Medals have been awarded by the Franklin Institute, Philadelphia, Pa., as follows : Edwin Hubble, Mount Wilson Observatory, Carnegie Institution of Washington, Pasadena, "In recognition of his extensive study of the nebulæ, particularly those outside our galaxy, as a result of which the dimensions of observed space have been greatly increased" ; Albert Sauveur (posthumously), professor emeritus of metallurgy and metallography, Harvard University, "In recognition of his outstanding work in the science of metallography and of his many contributions to this branch of metallurgy which have been in a large measure responsible for changing the heat treatment of steel from an art to a science".

\section{Rare Frankliniana}

VISITORS to the recent exhibition of "Frankliniana" at New York City's Grolier Club (March 16-April 16) were impressed alike by the incomprehensible versatility of Benjamin Franklin's genius and by the fascinating rarity of many of the exhibits displayed. Printer, journalist, statesman, advocate of inoculation, inventor, and the most widely travelled American of his day, Franklin crossed the Atlantic Ocean eight times. That he was not unaware of the perils of travel is revealed by an obsolete will "written by my own hand while waiting for a passage to England" in 1757. By his classic kite experiment in 1748 he proved the identity of lightning and electricity, and his book "Experiments and Observations on Electricity", London, 1751, with a preface by his physician and friend Dr. John Fothergill, carried his fame over the civilized world. "Some Account of the Pennsylvania Hospital", Philadelphia, 1754, recalls that Franklin was instmumental in founding what is regarded as the oldest hospital, in the modern sense of the term, in the present United States. He served as the first clerk to the board of management and later as president. "Proposals for Promoting useful Knowledge among the British Plantations", 1743, is believed to be the earliest suggestion in printed form for an American Philosophical Society, to which the author offers his services as secretary. The pamphlet shown is de scribed as one of two copies known. His first book, "Dissertation on Liberty and Necessity, Pleasure and Pain", London, 1725, the young Franklin grew to dislike so violently that he destroyed all remaining copies except one. Other exhibits included a selection of his famous almanacs, so rare to-day, though originally issued in editions of 10,000 copies.

\section{Chaston Chapman Gift to the University of Leeds}

IN 1933 Mrs. Chaston Chapman presented to the University of Leeds her late husband's extensive working library of modern books on chemistry, together with complete runs of a large number of periodicals. Mrs. Chaston Chapman has now presented his collection of works on alchemy to the University of Leeds, where they are housed in the Brotherton Library. There is a small section of French books and a more extensive section of 